\title{
Teacher's Strategy for Increasing Students' Creative Thinking Ability Through Open-Ended Learning in Elementary Schools
}

\author{
Baharuddin 1), Andi Agustang ${ }^{2)}$ \\ 1) Postgraduate Education Administration Study Program, Universitas Negeri Makassar, Gunung sari \\ Baru, Bonto Langkasa Street, Makassar-90222 \\ 2) Universitas Negeri Makassar \\ Corresponding Author: Baharuddin, Email: baharuddin.heru@gmail.com
}

\begin{abstract}
History: Received 07/01/2022 | Revised 08/01/2022 | Accepted 20/01/2022 | Published 31/01/2022
Abstract. This research is based on students' creative thinking abilities, which can be influenced by two factors, namely internal factors, and external factors. As an external factor, the teacher is a facilitator in applying the right approach to the learning process. The learning approach applied by the teacher will have an impact on students' creative thinking abilities. This study aims at discovering (1) the description of the implementation of open-ended learning as a strategy to improve students' creative thinking ability at SDN Mangkura V Makassar, (2) the description of students' creative thinking ability before and after implementing open-ended learning approach at SDN Mangkura V Makassar, (3) the influence of the implementation of open-ended learning approach on students' creative thinking ability at SDN Mangkuira V Makassar. The type of research employed in this study is a quasi-experimental design with pretest-posttest nonequivalent control group design. Data were collected through observation, tests, and documentation. The research populations were all students of grade IV at SDN Mangkura V Makassar, with a total of 63 students. The sampling technique used in this study was non-probability sampling; thus, it obtained 54 students. Data were analysed by employing descriptive analysis and inferential analysis. The study results reveal that the mean score before the implementation of the open-ended learning approach is 29.26 , which is in a low category. After the implementation of the open-ended learning, approach is 45.70 , which is in the high category. It can be concluded that students' creative thinking skills increase through open-ended learning because, with open-ended learning, they have the freedom to express creative ideas in problem-solving.
\end{abstract}

Keywords: Creative Thinking, Open-Ended Learning

\begin{abstract}
Abstrak. Penelitian ini berlandaskan pada kemampuan berpikir kreatif siswa dapat dipengaruhi oleh dua faktor, yaitu faktor internal dan faktor eksternal. Guru sebagai faktor eksternal merupakan fasilitator dalam penerapan pendekatan yang tepat pada proses pembelajaran. Pendekatan pembelajaran yang diterapkan guru akan berdampak pada kemampuan berpikir kreatif siswa. Penelitian ini bertujuan untuk mengetahui (1) gambaran pelaksanaan pembelajaran open-ended sebagai strategi meningkatkan kemampuan berpikir kreatif peserta didik di SD Negeri Mangkura V kota Makassar, (2) gambaran kemampuan berpikir kreatif siswa sebelum dan sesudah pelaksanaan pembelajaran open-ended di SD Negeri Mangkura V Makassar, (3) pengaruh pelaksanaan pembelajaran open-ended terhadap peningkatan kemampuan berpikir kreatif peserta didik SD Negeri Mangkura V Makassar. Jenis penelitian yang digunakan dalam penelitian ini adalah Quasi Experimental Design dengan desain Pretest-posttest nonequivalent control group design. Teknik pengumpulan data melalui observasi, tes, dan dokumentasi. Populasinya adalah seluruh siswa kelas IV SD Negeri Mangkura V Makassar sebanyak 63 orang siswa. Teknik penyampelan yang digunakan adalah non probability sampling sehingga diperoleh sampel sebanyak 54 orang siswa. Teknik analisis data yang digunakan adalah analisis deskriptif dan analisis inferensial. Hasil penelitian menunjukkan bahwa rata-rata (mean) skor sebelum pelaksanaan pembelajaran open-ended adalah 29,26 dengan kategori rendah dan sesudah pelaksanaan pembelajaran open-ended adalah 45,70 dengan kategori tinggi. Dapat disimpulkan bahwa kemampuan berpikir kreatif meningkat melalui pembelajaran open-ended karena dengan pembelajaran open-ended, peserta didik memiliki kebebasan berkreasi menuangkan gagasan kreatif dalam pemecahan masalah.
\end{abstract}

Kata kunci: Berpikir Kreatif, Pembelajaran Open-Ended 


\section{INTRODUCTION}

In the knowledge age, learning is described as a learning process designed by teachers to develop creativity or a way of thinking that aims to improve the ability of students related to the process of constructing new knowledge as an effort to improve good mastery of the subject matter. Learning can also be defined as the teacher's efforts to provide stimulus, guidance, direction, and motivation to students to allow the learning process to occur. Learning in this sense is not a knowledge learning process but a knowledge formation process by students through their cognitive performance (Etistika Yuni Wijaya et al., 2016).

New standards or guidelines are needed to have the competencies required for the $21 \mathrm{st}$ century. Schools are challenged to find a variety of strategies or ways that can enable students to succeed in work and life through mastering creative thinking skills, flexible problem solving, collaboration, and innovation (Zubaidah, 2016).

(Muhali, 2019) explained that the world demands the education system to better prepare students for 21 st-century competencies to face more complex challenges now and in the future. Referring to this explanation, learning must create conditions where students can be creative and innovate instead of being dictated and intimidated by the teacher. Teachers should always be facilitators to develop students' creative thinking skills.

In accordance with Government Regulation number 19 of 2005 concerning National Education Standards, article 19, paragraph 1 explains that the learning process in each school or academic unit is carried out interactively, inspiring, fun, challenging, motivating students so that these students can contribute actively, as well as providing adequate space for the initiative, creativity, and independence based on the talents, interests, and physical and psychological development of students (Indonesia, 2005).

(Buchari, 2018) explains that the teacher has a very important role in the teaching and learning process. The teacher as the executor of the teaching and learning process so that teaching success will determine the success of students in learning, so it is natural and appropriate if in the learning process teachers are required in addition to their mastery of science and technology, they are also required to be able to have an approach, model, strategy, method and technique. Specific techniques are balanced with his understanding of the characteristics of each student he encounters.

Insight or knowledge that is qualified is indeed mandatory for educators, in this case, teachers. Still, it is not enough for an effective learning process because knowledge will be more meaningful if obtained through a construction experience by students both 
individually and in groups. Teachers have a role in facilitating by designing learnercentered learning strategies. The teacher is a facilitator whose function is to provide opportunities for students to optimize problem-solving abilities by using learnercentered strategies, where students have greater freedom and autonomy (Teachers \& Education, 2013).

According to (Kurikulum et al., 2013), the issuance of the 2013 Curriculum for all primary and secondary education units is one of the central and strategic steps to strengthen character towards a civilized Indonesian nation. The substance is developed to form humans, in this case, students who are intellectual, competent, and have character. As the front line of implementing the 2013 curriculum, teachers are expected to improve their professionalism. As the subject of learning activities following the 2013 curriculum, students are also expected to play an active role in the learning process.

(Trisnawaty et al., 2017) states that the shift in the learning paradigm from teachercentered classroom activities to studentcentered learning not only has an impact on learning activities but also impacts the process and learning outcomes themselves. In this case, the teacher has a role and function to make learning meaningful and create a pleasant learning atmosphere through a learning approach. As a facilitator and mediator, to develop students' creative thinking skills, a teacher should provide accessible opportunities for students as subjects of learning to seek and find the information and solutions needed and the benefits of the knowledge they get. Because free option means not tied to a monotonous approach, they must be actively involved in learning by finding out and doing something with several alternatives to develop their creative thinking skills.

Target-oriented learning of material mastery and limited ways of solving problems in learning has not been able to produce active, creative, and innovative students in education. In a little way, students succeed in short-term memory but fail to equip students to solve problems in the long term. Therefore, there needs to be a change in learning approaches that are more meaningful and varied to equip students to face the problems of life now and in the future (Panjaitan, 2016).

SD Negeri Mangkura V Makassar City is one of the schools that has implemented various methods in learning. However, based on preliminary observations made by researchers, unstructured interviews with class IV a and IVb teachers, and document studies at SD Negeri Mangkura V Makassar City, the variation of learning used has not led to aspects of increasing students' creative thinking skills. Teachers provide more material than students learn the material. As a result, many students seem bored and active, all of which interfere with the learning atmosphere. Students are 
also less given the opportunity to play an active role in learning and quickly forget the material that has been delivered in class. When giving practice questions, students only imitate what the teacher does, and in solving questions, students think that it is enough to do what is exemplified. In addition, if students are not able to solve it in the way that the teacher practices, then the solution is they solve it by copying the work of students who understand that way. As a result, students lack the ability to solve problems with other alternatives. Of course, this can interfere with the ongoing learning process and inhibit students from thinking creatively.

(Khoiri et al., 2017) defines that "creative thinking is an important skill to be improved and developed because this ability is not acquired from birth, but rather something that is obtained and honed by collaborating in learning." This statement implies that creative thinking needs to be developed, which requires external stimulus by the teacher. In this case, creative thinking is very important and needed by students to solve the learning problems they face.

Thinking creatively is an essential element in learning, especially learning mathematics. Few primary or secondary school education units are still less focused on these abilities, by knowing students' creative thinking abilities, the teacher gains insight or broader ways related to the potential and talents of their students (Semarang \& Articles,
2012). And to develop or improve students' creative thinking skills, teachers need an approach in learning where this approach gives students the freedom to carry out investigations and find alternative problem solving (Sanjaya, 2012).

In learning mathematics and other fields, thinking is an essential part of life skills for development, especially in dealing with or preparing students in the information age and increasingly competitive atmosphere. In this case, students who are allowed to think creatively will grow and have the ability to face challenges. On the other hand, individual students who are not facilitated by creative thinking will undoubtedly become frustrated and dissatisfied. The development of this innovative thinking ability activity involves imagination, intuition, and discovery with strategies for developing divergent, original thinking, curiosity, making predictions and conjectures and trying new things in problemsolving in the learning process (Syarifah, 2017).

(Noviyana, 2017) explains that the ability to think creatively is essential for students, which will give birth to the next generation of creative people who can create opportunities for their future lives. So that one of the learning approaches that can be applied and mediates students to think creatively to solve problems in learning is open-ended learning. 
In this case, the open-ended problem in learning in question is a problem that has various solutions or solutions to the task, where the aim is not explicitly stated in the situation, so students must build specific goals for the work or task being completed (Prihartini et al., 2016).

Open-ended learning allows students to play an active role in encouraging creative thinking skills. This is because open-ended learning can free or liberate students in the learning process so that they are more interested in learning and more creative to come up with problem-solving ideas in each learning process (Mukti \& Soedjoko, 2021).

Students must make observations, ask questions, determine relationships, display reasons, and draw conclusions through the open-ended learning approach. Therefore, open-ended learning can be used to help develop creativity, especially in terms of students' thinking skills. In addition, this approach is expected to overcome student problems which are one of the inhibiting factors for learning activities. This is in line with the opinion (Widiasworo, 2017), which suggests that the most frequently complained by educators in this case the teacher is the problems of students in classrooms that can interfere, even hinder the activities of the course of a learning process. So that openended learning is needed to overcome difficulties in learning.
In connection with this explanation, it can be described the suitability between the results of research that has been carried out by (TYE Siswono, 2005) which describes that to overcome the aspects of students' creative thinking weaknesses, proper learning is needed, one of which is learning by submitting problems that lead to critical and creative attitude. However, the results of this study have not met the expected increase in all components of creative thinking skills. A learning approach is needed that can cover all elements of creative thinking skills that are not just posing problems. From this description, the relationship between teacher and student aspects that want to be investigated in this study is about the possibility of the effect of open-ended learning on increasing the creative thinking skills of students at SD Negeri Mangkura V, Ujung Pandang District, Makassar City.

\section{RESEARCH METHODS}

The type of research used in this study was quasi-experimental research. Quasiexperiments were used because the control group could not function fully to control external variables that affect the implementation of the experiment. This quasiexperimental method was based on the consideration that the implementation of this research takes place naturally and students do not feel experimented (Yandari \& Kuswaty, 2017). The number of respondents in the study 
were 27 students in the experimental class and 27 students in the control class at SD Negeri Mangkura V Makassar. The data collection techniques used by researchers are observation, tests, and documentation. The instruments used in this study were:

1. Teacher observation sheets managing learning.

2. The observation sheet includes the student and teacher activity observations sheets.

3. A problem-solving ability test in math problems related to open-ended questions.

The instruments in this study were supported by learning tools, namely Lesson Plan and Student worksheets.

The design of this study was in the form of the Nonequivalent Control Group Design, where both the experimental group and the control group were compared, even though the group was selected and placed without going through random. The population in this study was all fourth-grade students at SD Negeri Mangkura V Makassar, which consisted of two classes totaling 63 students divided into two groups, namely the experimental group and the control group. The sample in this study used a non-probability sampling technique, namely the type of purposive sampling. The sample members in this study were determined based on the formula by Slovin, namely:

$$
\mathrm{n}=\frac{N}{1+N e^{2}}
$$

So that the number of samples that will be used in this study is 54 students divided into two groups based on the results of data tabulation, namely 27 students for the experimental class and 27 students for the control class.

The data analysis technique in this study used descriptive statistical techniques and inferential statistical analysis techniques. Inferential statistical analysis was used to test the research hypothesis using the t-test. Based on the results of the Independent Samples TTest, it shows that open-ended learning can improve students' creative thinking skills.

\section{DISCUSSION}

According to (Baharuddin, 2019), the level of creative thinking ability of fourthgrade students at SD Negeri Mangkura V Makassar, before the implementation of openended learning showed that the experimental group was mostly between scores of 17 to 38 , as well as scores of creative thinking abilities of control group students. Most of the students in the experimental class are between scores of 17 to 38. After the implementation of openended learning, most students in the experimental class are between scores of 39 to 60 while in the control class, most of the students are between scores of 28 to 49 . After the implementation of open-ended learning in the experimental class, the average (mean) score of the creative thinking ability of the experimental class students increased and reached an average of 45.70 in the high category, and the control class reached an average of 35.41 in the low category. 
The results of the research above are in line with the results of research that has been carried out by (Noer, 2011), where the research was conducted at the junior high school level with the results based on data analysis carried out, it was concluded that there was a difference in the average increase in creative thinking skills between students who took part in the study. Learning in the two sample groups. In the experimental group, students' creative thinking skills increased.

Discussion about the implementation of open-ended learning at SD Negeri Mangkura V Makassar, it can be stated that the implementation of open-ended learning can improve students' creative thinking skills because with open-ended learning, students have the freedom to be creative in expressing creative ideas in problem-solving as stated by (Mukti \& Soedjoko, 2021).

Open-ended learning provides open problems with solutions that are not single or can be solved in various ways. Learning strategies using open-ended provide flexibility or freedom for students to express or find various alternative answers to the questions given. This can help students solve problems with their own creativity and make students appreciate the diversity of thinking during the problem-solving process (Widiastuti \& Putri, 2018). Likewise, with creative thinking, with the freedom that students have more freedom to develop innovative ideas in problemsolving so that students can be more fluent, flexible, and find new things to solve problems. This explanation is in line with the explanation, which states that the problem formulation used in learning with an openended approach is an open problem. The open problem referred to here is a problem that has many solutions or settlement strategies. In this approach, students are expected to find their solutions, provide arguments related to answers, and describe how students can arrive at the answers they use or find (Fauziyah, 2017).

Likewise, for teachers in the implementation of open-ended learning, the teacher only acts as a facilitator and no longer emphasizes that students must follow the way they are taught, which can hinder creativity. Teachers are wiser to give the students the broadest possible freedom to solve the problems presented. The ability to think creatively can be referred to as a unit or a combination of logical thinking and divergent thinking to produce something new or not as usual. Something new indicates the ability to think creatively (Tatag Yuli Eko Siswono, 2016). Creative thinking is one of the thinking skills required in the 2013 curriculum. Therefore, as an educator, teachers must make students become creative individuals. Thus, open-ended learning allows it to be used as one of the learning approaches in improving students' creative thinking skills at SD Negeri Mangkura V Makassar. Based on the data 
obtained in the field, the level of student's creative thinking skills before the open-ended learning approach was applied was in the low and very low categories, as seen from the students' scores after the pretest.

The results of the analysis showed that most of the students answered the questions with only one way of solving it with the usual strategy without any new solutions that were unusual at their level of knowledge. Even some students did not give answers to the questions that were done at the time of the pretest. This shows that the students' creative thinking ability is still low. (Mahardiningrum \& Ratu, 2018) suggests that creative thinking can be detected through several components, including those used in this study, namely fluency, flexibility, and originality. Through these components, students' creative thinking skills can be improved. Improving creative thinking skills means increasing students' ability scores in understanding problems, fluency, flexibility, and problem-solving novelty. Students can be concluded that they understand the problem if there is the ability to show what is known and what is asked. Students have fluency in solving problems if they can solve problems with various and logically correct answers. Students have flexibility in solving problems if they can solve problems in two or more different and correct ways. Students have novelty in solving problems if they can give answers different from the previous answers or generally known to students as usual (T. Y. E. Siswono, 2005).

The level of creative thinking ability of fourth-grade students at SD Negeri Mangkura $\mathrm{V}$ Makassar after the open-ended learning approach was implemented was in the high category as seen from the way students solved problems with various solutions when working on LKPD after learning took place. Most of the students have shown fluency, flexibility, and originality in completing LKPD in each meeting. The students' creative thinking ability has increased significantly, as seen from the students' scores after the posttest. Implementing the open-ended learning approach in the experimental class experienced a significant increase. This can be seen in the average value of the pretest, which has increased in the average value of the posttest. These results indicate that the implementation of the open-ended learning approach affects increasing students' creative thinking skills (Baharuddin, 2019).

The difference in learning activities between open-ended learning and learning activities that do not use open-ended learning will undoubtedly have a different impact on students' creative thinking abilities. Learning by applying open-ended learning in the experimental class gives the widest possible freedom to students to develop ideas, methods, strategies in problem-solving. With the freedom given through open-ended learning, students are more free to explore their potential 
and are more open to determining the desired alternative answers. Like the opinion (Karwono, 2017) which says that open education is an educational process that provides opportunities or flexibility for all students to move freely and determine their own learning activities to stimulate the emergence of creative ideas from each student happened. in the experimental class. While in the control class, the teacher does not give the students the widest possible freedom to develop ideas, methods, strategies in problemsolving. In the control class, students solve questions on students' worksheets with single answers or do not demand multiple answers. Students are not motivated to develop diverse ideas, methods, and strategies in problemsolving. Therefore, if learning by applying an open-ended learning approach is familiarized in the learning process, then students can then understand the content of the material quickly.

From these results, it can be concluded that open-ended learning can improve students' creative thinking skills that need to be socialized and applied at every level of education in particular. The implementation of open-ended learning in learning can be used as an alternative to improve students' creative thinking skills in elementary schools.

\section{CONCLUSION}

Students' creative thinking ability before applying open-ended learning is generally in the low category, while after implementing open-ended learning is in the high category. So it can be concluded that through open-ended learning, the students' creative thinking ability of SD Negeri Mangkura V Makassar increases.

\section{REFERENCES}

[1] Agustang, A., \& Sahabuddin, J. (2020, October). Model kolaborasi sosial pendidikan karakter di sekolah swasta kecamatan bissappu kabupaten bantaeng. In prosiding seminar dan diskusi pendidikan dasar.

[2] Agustang, A., Suardi, S., Putra, A. D. M., \& Oruh, S. (2021). Pemberdayaan Guru Mata Pelajaran Sosiologi Melalui Literasi Digital Berbasis Quick Response Code di Kecamatan Bissappu Kabupaten Bantaeng. Abdi: Jurnal Pengabdian dan Pemberdayaan Masyarakat, 3(2), 175-188.

[3] Baharuddin. (2019). PENGARUH PELAKSANAAN PENDEKATAN PEMBELAJARAN OPEN-ENDED TERHADAP KEMAMPUAN BERPIKIR KREATIF SISWA PADA SD NEGERI MANGKURA V MAKASSAR. Universitas Negeri Makassar.

[4] Buchari, A. (2018). Peran Guru Dalam Pengelolaan Pembelajaran. Jurnal Ilmiah Iqra', 12(2), 106. https://doi.org/10.30984/jii.v12i2.897

[5] Etistika Yuni Wijaya, Dwi Agus Sudjimat, \& Amat Nyoto. (2016). Transformasi Pendidikan Abad 21 Sebagai Tuntutan. Jurnal Pendidikan, 1, 263-278. http://repository.unikama.ac.id/840/32/263278 Transformasi Pendidikan Abad 21 Sebagai Tuntutan Pengembangan Sumber Daya Manusia di Era Global .pdf. diakses pada; hari/tgl; sabtu, 3 November 2018. jam; 00:26, wib.

[6] Fauziyah, L. (2017). Model Problem Based Learning dengan Pendekatan Open-Ended untuk Meningkatkan Kemampuan Pemecahan Masalah Siswa. Unnes Journal of Mathematics Education Research, 6(1), 5967. 
[7] Indonesia, P. R. (2005). RPP_SNP_24 April_2005 1.1-46.

[8] Karwono, H. M. (2017). BELAJAR DAN PEMBELAJARAN SERTA PEMANFAATAN SUMBER BELAJAR (1st ed.). PT. RAJAGRAFINDO PERSADA.

[9] Khoiri, N., Riyadi, S., Kaltsum, U., Hindarto, N., \& Rusilawati, A. (2017). Teaching Creative Thinking Skills with Laboratory Work. International Journal of Science and Applied Science: Conference Series, 2(1), 256.

https://doi.org/10.20961/ijsascs.v2i1.16722

[10] Kurikulum, P., Sp, D. K. T., Pack, P. D. F., Kurikulum, D. P., Eri, M. A. T., Dinamika, U., \& Kurikulum, P. (2013). Dalam Pembelajaran Di.

[11] Mahardiningrum, A. S., \& Ratu, N. (2018). Profil Proses Berpikir Kreatif Matematis Siswa Dalam. Journal of Authentic Research on Mathematics Education (JARME), 7(1), 39-50.

[12] Muhali, M. (2019). Pembelajaran Inovatif Abad Ke-21. Jurnal Penelitian Dan Pengkajian Ilmu Pendidikan: E-Saintika, 3(2), 25. https://doi.org/10.36312/esaintika.v3i2.126

[13] Mukti, A. A. B., \& Soedjoko, E. (2021). Kemampuan Siswa pada Aspek Berpikir Kreatif Ditinjau dari Gaya Belajar Melalui Pembelajaran Problem Posing Berbasis Open-Ended Problem. PRISMA, Prosiding Seminar Nasional ..., 4, 26-36. https://journal.unnes.ac.id/sju/index.php/pris $\mathrm{ma} /$ article/view/44955

[14] Noer, S. H. (2011). Mengembangkan Keterampilan Berpikir Kreatif Matematis dan Pembelajaran Matematika Berbasis Masalah Open-Ended. Jurnal Pendidikan Matematika, 5(1), 100.

[15] Noviyana, H. (2017). Pengaruh Model Project Based Learning Terhadap Kemampuan Berpikir Kreatif Matematika Siswa. JURNAL E-DuMath, 3(2). https://doi.org/10.26638/je.455.2064

[16] Panjaitan, D. J. (2016). Penerapan pendekatan contextual teaching and learning ( Ctl ) untuk meningkatkan hasil belajar statistika. Jurnal Pendidikan Mipa, 1(1), 110 .

[17] Pengajar, S., \& Pendidikan, P. (2013). *) Staff Pengajar Prodi Pendidikan Geografi, FIS, Unesa. $1(12), 1-11$. http://geo.fish.unesa.ac.id/berkas/sukma/me mfasiltasi_pembelajaran.pdf

[18] Prihartini, E., Lestari, P., \& Saputri, S. A. (2016). Meningkatkan Kemampuan Berpikir Kritis Matematis Menggunakan Pendekatan Open Ended. Prosiding Seminar Nasional Matematika IX 2015, 58-64.

[19] Sanjaya, I. P. H. (2012). PENGARUH MODEL PEMBELAJARAN INKUIRI LABORATORIUM TERHADAP KETERAMPILAN BERPIKIR KREATIF DAN KETERAMPILAN PROSES SAINS SISWA DITINJAU DARI KEMANDIRIAN BELAJAR SISWA. JURNAL PENDIDIKAN DAN PEMBELAJARAN IPA INDONESIA, 2, 1-15. https://ejournalpasca.undiksha.ac.id/index.php/jurnal_ipa/is sue/view/45

[20] Semarang, U. N., \& Artikel, I. T. (2012). Analisis Proses dan Kemampuan Berpikir Kreatif Siswa dalam Matematika Melalui Tugas Open-Ended. Kreano: Jurnal Matematika Kreatif-Inovatif, 3(2), 91-99. https://doi.org/10.15294/kreano.v3i2.2616

[21] Siswono, T. Y. E. (2005). Upaya meningkatkan kemampuan berpikir kreatif siswa melalui pengajuan masalah. Jurnal terakreditasi "Jurnal Pendidikan Matematika dan Sains." "Jurnal Pendidikan Matematika Dan Sains" FMIPA Universitas Negeri Yogyakarta., Tahun X, N(ISSN 1410-1866), 1-9.

https://d1wqtxts1xzle7.cloudfront.net/31423 532/paper05_problemposing-with-coverpagev2.pdf?Expires $=1632886327 \&$ Signature $=\mathrm{Cf}$ q5ufEa1 VMtjNiD8JCnZDupeQOrZF4fDAcxRAdFv6OZTi3PsaVG Cbn jHPfVIZr79vheKjQrwH2X TeuCVdZJJ5Y kTD0XBnSA3tAQhDN5pzFC76frJDIWb1d kcfAUVdoIg3

[22] Siswono, Tatag Yuli Eko. (2016). Berpikir Kritis dan Berpikir Kreatif sebagai Fokus Pembelajaran Matematika. Seminar Nasional Matematika Dan Pendidikan Matematika (Senatik 1), 11-26. 
[23] Syarifah, L. L. (2017). Pengaruh Pendekatan Open ended Terhadap Kemampuan Berfikir Kritis Matematik Siswa. Jurnal Program Studi Pendidikan Dan Penelitian Matematika, 6(1), 91-101. http://jurnal.umt.ac.id/index.php/prima/inde $\underline{\mathrm{ks}}$

[24] Suardi, S., Agustang, A., \& Jumadi, J. (2021). Dominasi Sekolah Negeri Terhadap Sekolah Swasta Sebagai Penyebab Kekerasan Simbolik Terhadap Siswa Sekolah Swasta. Jurnal Ilmiah Muqoddimah: Jurnal Ilmu Sosial, Politik dan Hummanioramaniora, 5(2).

[25] Trisnawaty, W., Ibrahim, M., \& Wihono, B. S. (2017). Pengembangan Instrumen Asesmen Yang Berpusat Pada Siswa Dalam Pembelajaran Fisika. JPPS (Jurnal Penelitian Pendidikan Sains), 1(1), 1. https://doi.org/10.26740/jpps.v1n1.p1-5

[26] Widiastuti, Y., \& Putri, R. I. I. (2018). Kemampuan Berpikir Kreatif Siswa pada Pembelajaran Operasi Pecahan Menggunakan Pendekatan Open-Ended. Jurnal Pendidikan Matematika, 12(2), 1322.

https://core.ac.uk/download/pdf/267822167. pdf

[27] Widiasworo, E. (2017). MASALAHMASALAH PESERTA DIDIK DALAM KELAS DAN SOLUSINYA (Vita Nur A. (ed.)). Araska.

[28] Yandari, I. A. V., \& Kuswaty, M. (2017). Penggunaan Media Monopoli Terhadap Peningkatan Kemampuan Pemahaman Konsep Matematis Peserta Didik Kelas V Sekolah Dasar. Jurnal Pendidikan Sekolah Dasar, 3(1), 10. https://doi.org/10.30870/jpsd.v3i1.1037

[29] Zubaidah, S. (2016). Keterampilan Abad Ke21: Keterampilan Yang Diajarkan Melalui Pembelajaran. Seminar Nasional Pendidikan Dengan Tema "Isu-Isu Strategis Pembelajaran MIPA Abad 21, Desember, 117. 